\title{
Positive Spillover of Political and Technological Crises on Persons, Organizations, and Destinations across Covid-19: A Data Triangulation Study
}

\author{
Anthony E. Onyeama \\ Faculty of Tourism, Eastern Mediterranean University, Gazimagusa, TRNC, via Mersin 10, Turkey \\ Email: anthonyeonyeama@gmail.com
}

How to cite this paper: Onyeama, A. E. (2021). Positive Spillover of Political and Technological Crises on Persons, Organizations, and Destinations across Covid-19: A Data Triangulation Study. Open Journal of Political Science, 11, 488-521. https://doi.org/10.4236/ojps.2021.113033

Received: January 10, 2021

Accepted: July 16, 2021

Published: July 19, 2021

Copyright (อ 2021 by author(s) and Scientific Research Publishing Inc. This work is licensed under the Creative Commons Attribution International License (CC BY 4.0).

http://creativecommons.org/licenses/by/4.0/ (c) (i) Open Access

\begin{abstract}
Crises are now parts of daily experience, peoples, organizations, and destinations experience crises. Most times, it occurs without realizing it, and even when people take note, it is the negative spillovers that are often emphasized more than the positive spillovers. Little do people realize that the crisis they are in today prepares them for tomorrow's strength. Unfortunately, there is little or no literature on the positive spillovers of crises. This study aims to fill the literature on the positive spillover of crises on peoples, organizations, and destinations using a qualitative data triangulation, comprising face-to-face interviews and textual data. The study employed spillover effect and resilience theories to justify the arguments. Findings from stage 1 analysis revealed three themes, and stage 2 analyzes supported the findings. Most times, survivors of crises end up becoming resilient after an experience. This study discussed managerial and practical implications, as well as limitations and future studies.
\end{abstract}

\section{Keywords}

Covid-19 Crisis, Political Crisis, Resilience, Spillover Effect, Technological Crisis

\section{Introduction}

Nowadays, crises are part of daily life, a sine qua non, and a challenge faced by peoples, organizations, and destinations, both locally and internationally. This shows the attributes of crisis in its three-folds; threat to the individual or organ- 
ization, the sudden process of occurrence, and limited decision-making time. Usually, no one prays to experience a crisis, but most times, crises occur without permission and are not foreseeable. However, sometimes starting with recognizable signals are conditions emergence of which might depend on many causes (Yelkikalan \& Köse, 2012). But whenever it occurs, it creates a series of experiences. These experiences weaken the individual mindsets. Still, it fortifies survivors. I think therefore Robert Tew (n.d.) says: "the struggle you're in today is developing the strength you need tomorrow". But a question that comes to mind is; who will accept crises? Besides, periods of crises can become an opportunity for organizations through corporate social responsibility (Souto, 2009) for peoples and destinations simultaneously. There are studies on crisis management, communication, intervention, response, and etcetera.

Unfortunately, literature on the positive spillover of crises on persons, organizations, and destinations is scarce. Decades ago, several studies focused on the positive and negative effects of the crisis on organizations, for instance, (Özdemir \& Balkan, 2010). Also, there are studies on the effects of the global economic crisis and its aftermath on the banking centers, for instance, (Blazek, Hejnova, \& Rada, 2020). Others studied the effects of the economic crisis on mental healthcare, for instance, (Silva, Resurrección, Antunes, Frasquilho, \& Cardoso, 2020). Still many others wrote on crisis management, for instance, (Bieling, \& Guntrum, 2020; Burden, 2020; Tocci, Presta \& Volpe, 2020; Papadopoulos, 2020). And a few others wrote on disaster resilience and sustainability, for instance, (Keating \& Hanger-Kopp, 2020; Pal, Meding, Shrestha, Ahmed, \& Gajendran, 2020). Unfortunately, studies on the positive spillover of crises on persons, organizations, and destinations are scarce. This study is necessary because persons, organizations, and destinations are three inseparable entities that bear the consequences of any crises, such that; it may transfer the effects of the crisis to system boundaries by organizational relationships (Scott \& Laws, 2006) affecting these three.

This study aims to fill the literature on the positive spillovers of crises on persons, organizations, and destinations. Hence, this study suggests that crises have the potential to create positive spillovers irrespective of individuals, nature, context, and/or time. Sometimes survivors end up becoming resilient after an experience. The current study employed two units of analysis (scenarios of crises); Political and Technological crises.

\subsection{First Scenario}

The first scenario is a political crisis. There are academic literatures on political crisis, for instance, (Nunes \& Melo, 2017; Sousa, Corrêa, Ville, \& Quiñonez, 2019; Silva, 2020). Unfortunately, almost all the literatures lack the definition of the term. This may not promote knowledge transfer hence, the need to encourage the definition of article key terms before diving into different aims of the study. This will trigger updates for knowledge transfer. However, the current study defined political crisis as a situation where failing to satisfy certain demands of dif- 
ferent parties (oppositions parties) or a state where the quest for certain goals by opposition parties or ruling power results in tough government reaction and can involve the use of military or violence such as coup d'état, subjugation, bombing or protests. For instance, coup attempts (Adisonmez \& Onursal, 2020) as a strategy cleanses regimes from a mess. Coups can open alternative ways to establish a fortified regime. More precisely, successful coups and/or failed coups can develop significant opportunities for the ruling regime to sanitize and strengthen its governance by identifying unfriendly friends and eliminating the bad eggs from the good ones (Powell, Chacha, \& Smith, 2019). Though coups relate to negative events yet, it has positive spillovers on persons, organizations, and destinations (ripple effects) after each encounter.

Supporting this scenario, a quote by President Recep Tayyip Erdogan of Turkey after the attempted coup of 2016 says; "This uprising is a gift from God to us because this will be a reason to cleanse our army", (Movement, Erdoğan, Ylldırım, Akar, Dündar, \& Gülen, 2016-17). Recall that in a normal situation, the action of identifying and having a cleansed regime is mostly difficult to actualize by a ruling power, but through coup d'état, the impossible may become possible. This, therefore, shows that though the coup crisis may have some negative memories yet, its positive potential showcases afterward. Each time a regime (the ruling power) keeps its position after a coup, the more resilient it becomes, bouncing back, and becomes rigid against future campaigns, this is resilience in action; (Larcos, Prgomet, Georgiou, \& Westbrook, 2017).

On the other side, the failed plotters (rivals), the unelected guardians, and or the self-seeking politicians though might have received their penalties, yet they must have learned their lessons which if given a second chance can prove robust and resilient in carrying out a successful coup. Such is the case with Nkurunziza's determination for a third tenure in office that resulted in a failed coup in May 2015. On this note, Bjørnskov and Pfaff (2018) opined that differences in regime types matter in the study of coup d'état especially, between post-coup democratization and civilian autocracies. So, while post-coup decreases respect for physical integrity rights when non-democratic regimes overthrow democratic regimes, it increases respect for physical integrity rights ordinarily. The following quotes support this;

"The unelected guardians aligned with the military's support for the Republic's founding principles would thus be entrusted with a liberal standing doctrine to clean up what the military viewed as 'the mess' that self-seeking politicians would inevitably create" (Varol, 2012). With this information, the current study suggests that crisis irrespective of destination, nature, time of occurrence, and successful or attempted (failed) coups still have potentials for positive spillovers after the events.

\subsection{Second Scenario}

The second scenario is a technological crisis. This type of crisis relates to human beings because technology is subject to human manipulation (Susser, Roessler, \& 
Nissenbaum, 2019). These crises, such as software failures and industrial accidents, occur and create room for resilience, improvement, and innovation. A technological crisis is a situation where and when common technological appliances and tools used in daily activities are shutdowns, hindered from functioning, or demands immediate attention. Further, it is periods of negative growth in patenting activity (Balland, Rigby, \& Boschma, 2015) but it has the potentials for positive spillovers if well managed. For instance, the effect of the Chernobyl nuclear disaster in Ukraine in 1986 led to more biologically thriving species (Itoh, 2018).

The technological revolution in the current day has created a quest for robust and resilient tech-savvy search engines and experts. But unlike the traditional search technologies, artificial intelligence technologies (AIT) now help tour operators and other travel agencies solve the crisis of duration, selecting \& analyzing tourist's routes in their offices by using AIT to reduce the time of selection and analyzing large volumes of data to fulfill customer orders as a competitive advantage against traditional engines (Kazak, Chetyrbok, \& Oleinikov, 2020). The technological crisis brought by economic or technological revolutions, for instance, (Leandros \& Papadopoulou, 2020), tech professionals such as the media and tour operators seek to adapt to the challenges by acquiring the technical know-how to become technologically resilient. This experience highlights the three dimensions of resilience which includes; 1) the ability to withstand periods of technological slowdown/crisis, 2) the ability to reduce the intensity of the crisis, and 3) the ability to shorten the duration of crisis events (Balland, et al., 2015) as against attributes described above; 1 ) threat to the individual or organization, 2) the sudden process of occurrence and then, 3) limited decision-making time (Hunt, 2020). Indeed, a technological crisis can positively spillover for resilience and promote opportunities for a better experience in managing lives, organizations, and destinations. So, in any crises, we need to look beyond the periphery to see the positive sides that may trigger resilience. This may lead to positive word of mouth about such persons, organizations, and destinations, and destination brand equity such as image \& perceived quality (i.e. destination resilience), awareness, and loyalty relates to customer satisfaction (Martín, Herrero, \& de los Salmones, 2019), and customer based brand equity such as brand image, perceived quality, and brand loyalty significantly relates to hotel organizations (Kayaman \& Arasli, 2007), these components may show the persons', organizations', and/or the destinations' resiliency after any crises experience.

\subsection{The Influence of Covid-19 Crises}

Introducing the Covid-19 crisis into the scenarios will make more sense in this discussion and could therefore reveal a clear picture of what the crisis looks like. The Covid-19 crisis is a global health pandemic ever faced after world war two and classified as SARS-CoV-2 by the World Health Organization in late 2019. It is a type of crisis with ripple effects in that its emergence has negative spillovers 
(Ouyang, Yao, \& Hu, 2020) but with some positive effects (Karunathilake, 2020) on diverse sectors of life. Further, some negative spillovers of the Covid-19 crisis include but are not limited to loss of lives, border closures, social distancing, face-masking. Its positive spillovers cut across global boundaries. These may include; discovery of indigenous medicine, reduction in crime, weather free from pollution, new recruitment policy for new employees, reduction in sex work for the fear of infection and stronger ties \& family bonding (Ahmed, Buheji, \& Fardan, 2020). Note that while crisis erupt, it also creates rooms to crack brains for solutions, thus the myth; human beings only make use of 10 percent of their brain's capacity. In such a case, one may ask; what happens to the remaining 90 percent of the brain's capacity? Here lies the information: during crises, the brain capacity actively increases beyond normal functions to engage much faster by taking in information, processing the information, and acting on them. Unlike in non-crisis periods, almost every major part of the human system wakes up to respond to sudden threats. Karras, Arriola, McCarten, Britton, BestermanDahan, \& Stecker (2020) studied the veteran perspectives of barriers and facilitators to campaigns promoting help-seeking during a crisis, it recorded unique experiences. First, a participant opined that concentration and focus were very difficult and had the option of just tunnel vision the thought of ending oneself. Other participants who struggled to focus opined that in crisis, it is difficult to capture the brain because it is about 99 percent focused on solving the problem. This means that; the brain is at a higher functioning capacity, building solutions to threats. Simply; crisis creates sudden rooms for positive spillovers than in non-crisis periods.

\subsection{Significance of This Study}

1) This study filled the literature on crises, precisely the positive spillover of crises on persons, organizations, and destinations, and laid the foundation that will improve knowledge transfer. 2) It brings hope and words of encouragement thus; "the struggle you're in today is developing the strength you need tomorrow" with proven evidence from persons, organizations, and destinations experiencing different crises to shake off failures and stir up spirits of resilience through stability and perseverance as true signs of robustness after any encounter. 3) Crises increase investments in technological and political sectors. Unlike the findings by (Zubair, Kabir, \& Huang, 2020), for instance, during technological crises, organizations may increase the level of investments in research and development on modern techs to survive challenges. Politically, the government may also intervene by investing in strategic advances. 4) These evidences validate spillover and resilience theories along with Brand24 analytical tool. This shows that crises can spillover for resilience after any encounter. Therefore, persons, organizations, and destinations are to be optimistic during crises. 5) Crises can also benefit destinations, for instance, the case of the Australian Bushfire turned out to be a seasonal outlook, and used by fire authorities to make strategic decisions such as resource planning and prescribed fire management to reduce 
the negative spillovers of bushfire (Australian Seasonal Bushfire Outlook: December 2020-February 2021), and this event can increase tourism development planning which generates revenue for host destinations. Such event also inspires destination marketers to do the craziest promotions, to stimulate travel exchange even in Covid-19 periods. Since bushfire is now a seasonal crisis in Australia, destination management can use this opportunity as a classical marketing intervention to create new experiences in using the tourism ecosystem, and re-evaluate the known market segmentation variables, and to consider postmodern consumer relations and value judgments in the formulation of successful marketing strategies (Kayaman \& Armutlu, 2003) Therefore, crises can positively spillover for destination wellness (Kazakov \& Oyner, 2021).

\subsection{Research Questions}

Based on this study, the researcher developed three research questions to guide the search terms through the application of the Brand24 analytical technique and procedurally amended according to the search engine, and this undertaking guided the analytical process.

1) What is the relationship between coups and the army?

2) Why is technology important during crises?

3) How do crises create benefits?

\subsection{Content Structure}

There are six chapters in this study. The above is chapter one, and it has details about the introduction to the current topic. Next is chapter two, and it is about literature reviews. Chapter three is about the method employed in this study, while chapter four is about details on the findings. And chapter five is about discussions then, the study ends with chapter six, which talks about limitations, future study, and conclusion.

\section{Literature Review}

\subsection{Political Crisis}

Literature on political crisis has increased recently with diversified findings. However, academic literature with definitions of political crisis is scarce. To promote knowledge transfer, there is a need to define key terms. Therefore, to the best of our knowledge, this study presents the first definition of political crisis. As earlier defined, a political crisis is a situation where failing to satisfy certain demands of different parties (oppositions parties) or a state where the quest for certain goals by opposition parties or ruling power results in tough government reaction and can involve the use of internal/external force, or violence such as coup d'état, subjugation, bombing or protests to bring the situation under control, for instance, (Zappettini \& Krzyżanowski, 2019; Nunes \& Melo, 2017; Duddy, 2015; Odeyemi, 2014; Hooghe, 2012; Uwanno, 2009 and Eppel \& Raftopoulos, 2008). Political crisis can relate to academic reformations, the process of leadership and 
management, communication etcetera. One of such pieces of literature explored the reform of higher education in Ukraine during the military-political crisis. The revolution and hybrid war with the Russian federation in 2013 brought along deteriorated consequences in many basic economic indicators. Yet, it speeded social reforms of the higher education system which usually host foreign students' training from 185 higher education institutions in the 2015/2016 academic term to 228 higher education institutions in the 2016/2017 academic term (Shevchenko, 2019). This is interesting because the crisis simultaneously and positively spilled over on students, education institutions, and Ukraine as a destination.

Similarly, coups which are harmful phenomena can bring positive change to install a fortified regime. Particularly, failed coups can become an opportunity to sanitize and strengthen a government by identifying and removing enemies (Powell et al., 2019). To support this, the president of Turkey, Recep Tayyip Erdogan opined;

"This uprising is a gift from God to us because this will be a reason to cleanse our army” (Movement, Erdoğan, Yıldırım, Akar, Dündar, \& Gülen, 2016-17). Under normal circumstances, an underdog remains the loser while the top dog/ favorite wins a competition. So if a coup crisis turns out to empower the ruling government, the event becomes positive for the ruling party.

Contrary to the above literature, periods of political crises bring challenges and disasters, thus, it is likely tough for individuals or groups to succeed or progress. However, if by any means persons or groups emerge successfully, such is likely termed resilience. Tippens (2020) studied the social capital and community resilience of urban Congolese refugees during political violence in Kenya. Findings showed that Congolese women refugees employed informal bonding social capital while their men employed bridging and linking networks to explore and allot resilience-promoting resources. These practices/programs (community resilience tactics) encouraged the integration, protection, and well-being of Congolese refugees to remain resilient in Kenya's political crisis events.

Interestingly, resilience practices identified with breaks in the arrivals of tourists and their recovery times. Breaks and recovery time were more associated with international tourists than with domestic tourists, implying that international tourists are less resilient than domestic tourists (Barbhuiya \& Chatterjee, 2020). Also, integrating resilient programs before and during political instability has significant benefits in tender ages. For instance, introducing students to skills for managing stress and anxiety at tender ages ensures resilience capability and wellbeing.

Strength based-approach for building resilience was used to examine wellbeing in schoolchildren in Gaza during political instability. Findings revealed that integrating resilience topics in the school curriculum such as building strong links between families, schools, and peer groups enhances children's ability to adapt even in conflicts (Jalala, Latifoglu, \& Uzunboylu, 2020). The above two 
studies confirmed that incorporating resilience programs into school children's academic curriculum helps the children to adapt positively even in crisis. With this information, the current study suggests that though political crisis has negative spillovers, yet, it also has positive spillovers that can spill over for resilience on persons, organizations, and destinations. But sometimes one may not see them until the events are over. This positive spillover can promote marketing in organizations, and/or destinations.

Understanding the relationships between these philosophical events is necessary, especially when talking about the positive or negative effects of a crisis from one different angle to another related or unrelated angle and in well \& bad times (Rigobon, 2019). For instance, the outcome of the 15th July 2016 attempted coup enabled President Tyip Edorgan to identify and punish his opponents. So, while they detained those captured, others lost their lives and survivors learnt lessons. Indeed, this is the reality of the spillover effect in action. Urbanist Jane Jacobs and John Jackson developed spillover effect theory in 1969. The crisis of malevolence i.e. crises caused by rivals who unfairly run an organization's businesses could also trigger this positive effect. For instance, global financial crisis and political corruption have links and could involve the securing of power and wealth through illegal ways for personal benefits. This causes abuse of power and can escalate into political, technical, or financial crises. This abuse of power can lead to one's personal, political, families and/or social class benefits (Ebegbulem, 2020). These considerations suggests that political crises can spill over positive experiences after any occurrences and creates a need for marketing by replacing, upgrade or bring to shape all damaged properties and equipment.

Unlike the study on European banking sectors (Blazek et al., 2020), Latif (2015) examined the impact of the economic crisis of 2008 on mental health in Canada. Findings revealed that the provincial unemployment rate had a significant positive spillover on depression. The above results suggest that there can be a positive spillover from economic crises, regardless of context. Even the financial crisis of 2008 had positive spillovers in that it created positive exchange rate for sub-sample 2008 to mid-2009 (weaker dollar versus Euro leads to higher stock returns), (Mollick \& Assefa, 2013). While some people were crying, others were thanking Almighty God for the new opportunity; as the effects positively favored them. The crisis benefited the northern and southern parts of Cyprus by using traditional banking systems instead of the unsophisticated banking systems in place, which had little reliance on international markets. Here, persons, organizations, and destinations escaped the brunt of the crisis because they maintained an out-dating-traditional banking system (Besim \& Mullen, 2009) which made it possible to record the current details on positive spillovers. Also, when people go through hard times, when things go wrong, when persons, groups or organizations face challenges, they look for solutions. Resilience theory is about recovering and adjusting (Parker, 2020) from stress-related events. Hence, the need to un- 
derstand why some patients and families thrive despite adversity, while others struggle (Stegenga, Liu, \& Haase, 2020).

Resilience is about being mindful and prioritizing behaviors, thoughts, and feelings that facilitate contentment within one's specific developmental, physical, emotional, and spiritual context. In line with this, the current study also suggests that persons, organizations, and destinations can thrive well in crisis and can well become resilient after experiencing any crises. Academic resilience literature, for instance, (Fang, Chan, \& Kalogeropoulos, 2020; Jalala, Latifoglu, \& Uzunboylu, 2020) involves advancing social and emotional learning programs that encourage people's (students') resilience, well-being, and involving resilience topics in their curriculum with positive thinking and child care. So, there is a positive significant relationship between academic resilience and social support from teachers, peers, and families. Based on these literatures, resilience programs directed for well-being support students' survival in crises.

Crisis theory holds that when the failure to satisfy specific demands, or a state where the quest for specific goals by any party results in civic revolution or brutal government reaction. Nevertheless, even in such a situation, such crises can create positive growth and change for significant experience. Note that the definition of crisis may be assumed as when a crisis ends, the new adaptation may or may not interest the survivors at the end of the crisis. This expression indicates that there are possible effects of positive spillovers of crisis. Milstein (2015) opined that the crisis experience had calibrated the aims of both politics and political theory, thereby rethinking the concept of crisis as the concept of political theory. This view means that crisis is parallel to politics because the context of crisis enhances the chances of policy change. However, it also increases the influence of policy entrepreneurs, such as policy experts and interest groups of political ideology and international actors (Wenzelburger \& Wolf, 2015) and politics. Generally, Lindemann's crisis theory holds that in human dilemmas, man's internal stability receives threats by specific changes, or "crises", in his social environment, which cause an acute disturbance. However, the individual's solution to the disturbance will either return him to his previous state of equilibrium or result in a "subsequent greater capacity for emotional wellbeing" (Harrison, 1965). In other words, experiences from a crisis can result in positive spillover and resilience. This event could emerge from a technological crisis too.

\subsection{Technological Crisis}

Considering the increase in technological crises, there should be equal increase in literature detailing the positive effects of technological crisis too. UKEssays (2018) defined technological crisis as a crisis caused by human application of science and complex technology leading to system breakdowns. But Weisæth, Knudsen Jr. and Tønnessen (2002) defined technological crisis using its characteristics thus; as a human-induced disaster resulting from failure of a human 
hand or in human-made products categorized as 1) transport systems such as air crashes, large-scale road accidents, train derailments, and collisions, passenger and other maritime catastrophes. 2) as the collapse of man-made constructions, 3) as a large fire of all sorts, and 4) as technological and toxic (nuclear power plant accidents, leakage of hazardous substances from waste disposal, etc.). However, studies focusing on the positive spillover of technological crises are scarce. On this note, improving the definition of technological crisis is necessary. Hence, a technological crisis is a situation where and when common technological appliances and tools used in daily activities breakdown, or demands immediate attention for total change, advancement for resilience, and/or innovations.

Innovation is a key to many successful organizations today. And one reason for industrial innovations may include technological crises. However, literature on technological crisis is scarce in recent years. Shrivastava (1994) suggested that crisis research over the past decades has emerged as a response to certain social problems such as the periodic occurrence of major technological crises, and the public's perception of risk shaped by the horror and enormity of damages caused by these events. Technological disruptions impact all facets of life, both structural (macro) and operational (micro) levels. But these advancements have the potentials to enhance service experience and develop the placement of advertisements and sponsored content (Giwa, Broderick, \& Omar, 2018). With the technological crisis, the current study suggests that the breakdown of technological devices both at the private, family, organizational, regional or state levels can create room to upgrade to standard versions thus ushering in artificial intelligence to manage customer orders, improve production, maintain a competitive advantage over competitors, and even create opportunities for marketing which may lead to resilience.

The definition of technological resilience in this study is the ability of an individual, group, or organization to sustain standardized service in the event of crises. For instance, according to service recovery perspective (Proença, Proença, \& Teixeira, 2020), (service performance below customer's expectations) it means creating adverse effects (crisis) during service encounter. But in line with the current study, recovering a failed service can create more goodwill than if things had gone smoothly in the first place, and through this procedure, recovery encounters would mean an opportunity for service providers to increase customer retention, (Bagherzadeh, Rawal, Wei, \& Torres, 2020; McQuilken, Robertson, Abbas, \& Polonsky, 2020; Khantimirov, Karande, \& Ford, 2020; Hart, Heskett, \& Sasser Jr., 1990) create a positive impact, and may lead to resilience. Further, "a good recovery can turn angry and frustrated (crisis experience) customers into loyal ones and can create more goodwill than if things had gone smoothly in the first place" (Hart et al., 1990). So, a recovery encounter can create positive spillovers as an opportunity to expand positive relationships (resilience) and promote positive word of mouth (marketing) about persons, organizations, and destinations respectively. 
Drawing from the recent Covid-19 outbreak (Li, Wu, Li, Yuan, \& Zhao, 2020), a supposedly, the outbreak was a technologically projected virus to attack and limit the potentials of China as an emerging world economy. Anyway, the outbreak is still claiming more lives as death rate tolls daily, and has halted production activities of Chinese technological transactions. These events created a golden opportunity for countries like India. Precisely, it has given an indirect spillover on many tech producers from other countries that get their raw materials from China, particularly mobile techs. Supporting this, Ramkumar, Head-Institutional Equities, IIFL says;

"The ill-fated coronavirus outbreak in China has offered India with an opening to receive the 'Make in India' program." Substantiated by the words of Chief Economic Advisor Krishnamurthy Subramanian thus;

"The coronavirus outbreak in China provides a good opportunity for India to expand trade and follow an export-driven model", "India has been following the same pattern in terms of mobile manufacturing in the country. So, if one looks from this perspective, it provides a good opportunity for India" (Will Coronavirus Shift Global Investment from China to India? 13 February 2020).

This shows that the technological shutdown in China which was indirectly caused by an outbreak of coronavirus still has the potentials to create positive spillovers for countries like India to prevail resiliently. This evidence supports the current study that; crises have positive spillovers on persons, organizations, and destinations.

A study analyzed the relative capacity to sustain the production of technological knowledge during crises in US cities. It focused on the vulnerability and response of cities to technological crises in periods of sustained negative growth in patenting activity. Findings revealed that; first, technological crises vary across American cities based on intensity, duration, and frequency. Second, cities with a diverse, flexible knowledge-base and proximate technologies without comparative advantage try to avoid technological crises at a minimal level in patent production and are resilient to crisis events (Balland et al., 2015). Further, a study on the perceived value of using mobile technology during a crisis of emergency evacuation in older adults revealed that the awareness and engagement of crisis apps were very limited based on the feelings that the crisis informatics tools addressed human values (Zhang, Suhaimi, Azghandi, Joseph, Kimdies, Griffin, \& Parker, 2020). These two studies show the importance of technological resilience and the need to create an awareness of technological developments. Based on this information, the current study suggests that technological awareness and alignment can spillover to technological resilience even during periods of crisis.

Interestingly, resilience literature also includes housing sectors. For instance, how service providers and supporters handled the challenges and opportunities of creating affordable and safe housing for New Orleans residents during crisis and recovery periods. Findings revealed that combating historically racial and market-oriented housing practices and policies that contributed to a growing 
housing affordability crisis depends on a political regime that has a local goal of creating affordable housing for low and moderate-income households is a workable strategy (Morris \& Diaz, 2020). Hence, creating models on project balance for resilience factors in crisis is a welcome progress (Bozorgi-Amiri, Jalilibal, \& Yakhchli, 2020). Based on the increasing need for resilience, organizations, regions, communities, and families are ceaselessly conducting studies on advanced resilience to combat crises. Hence, developing plans from the grassroots by bringing the local population to the center is a more promising approach than from the upper levels for a successful resilience in crisis. This was the case with the United Nations multidimensional integrated stabilization mission in Mali under resilience and conflict resolution (Ruffa, Rietjens, \& Nygren, 2020). Resilience can also be for the future, for instance, (Herbert, Ross, Whetter, \& Bone, 2020; Straub, Gray, Ritchie, \& Gill, 2020; Iborra, Safón, \& Dolz, 2020). With this information, the current study suggests that persons, organizations, and destinations can attain resilience even after any crisis experiences.

\subsection{Covid-19 Crises}

Crises have neither boundaries nor seasons; it cuts across politics to technological interventions. While crises create different spillovers, the Covid-19 crisis has some negative spillovers alongside positive spillovers. Politically, one of the positive spillovers of the Covid-19 crisis, is the politicization of palliatives by Nigerian politicians (Eranga, 2020) for election campaigns. While it was originally for the vulnerable, with no orders for distribution, certain political groups hijacked the aim for personal benefits.

Also, nationalism motivates political movement for a nation's interest against unwanted influences such as Covid-19 crisis, where differentiation politicizes for separation and partnering with organizations and or any of such partner union that withholds their free exercise of interests and political agendas. This was the case with the United States, where President Trump made a statement of withdrawing the US from the world health organization (WHO) for not meeting up with its mission of health and humanitarian help. The Covid-19 crisis has served as a weapon for political debates in the United States where the liberals are more concerned about Covid-19 pandemic solutions than the conservatives (Malloy \& Schwartz, 2020), and use the opportunity to fight the conservatives. Hence, politically, the Covid-19 crisis is a positive opportunity for the liberals to fight the conservatives. This information suggests that; crises have positive spillovers even after occurrence.

Technologically, the Covid-19 crisis generated a high demand for health technological solutions in the fight against the pandemic. Tech-savvy companies are increasing the search for more reliable technologies against the fast-spreading virus. This supports the saying; "health is wealth" because if you are healthy then, you can produce and deliver people's needs. Ordinarily, the growth rate of technology would have been normal, but the outbreak of the Covid-19 crisis triggered a high demand for technological developments in tracking and minimiz- 
ing the spread of virus infections. For instance, advanced artificial intelligencepowered tools were used to diagnose and screen the Covid-19 virus. These technologies are improving daily with complications from the Covid-19 crises. Besides, the inability of traditional techs to mediate between complex customer needs and organization resources led to an immediate increase of high-tech service deliveries and automation such as robotic drones for remote delivery. It is necessary to note that without these crises, some technological developments and innovations would not be in place.

Contrary to conventional beliefs, the periods of crises are times of negative spillovers. For instance, during the recent lockdowns, borders were closed, and many institutions could not operate, but the ugly situation was beneficial through work from homes using modern technologies, and customers could communicate with their respective organizations satisfactorily. During these periods, technicians advanced in modern multi-function technologies. For instance, photographers' use of digital cameras that could not navigate or capture incidents from distant places and from mass gatherings became easy through multipurpose drones that can fly and navigate in distant places wirelessly. These developments were born out of crises that ordinarily would not have taken place within the short periods. These evidences suggest that though technological crises may have negative spillovers, simultaneously, it has potential for positive spillovers such as increase in marketing etcetera.

The relationship between the Covid-19 crisis, political and technological crises is that; while Covid-19 crisis created opportunities for the political class for their own version of crises at different levels of operations, it created opportunities for medical and mechanical technicians to explore new ideas to contend with the dreadful virus as it continues to claim more lives. Besides, the good news is that; the incidents have several lessons, and many persons, organizations, and destinations emerged resiliently.

\section{Methodology}

\subsection{Study Design}

To gain a full understanding of this topic, qualitative data triangulation (Lemon \& Hayes, 2020) comprising face-to-face interviews and textual data is necessary. This provides a contextual description and interpretation of social phenomena (Mohajan, 2018). Also, face-to-face interviews receive higher performance ratings (Basch, Melchers, Kurz, Krieger, \& Miller, 2020) compared to other types of interviews. Besides, qualitative data triangulation allows the analysis of different textual data, and text data can come from print media articles, books, and interviews as electronic patterns (Kondracki et al., 2002). This research approach is suitable because of its flexibility in handling unique sources of data. The study design is in two stages. Stage 1 employed face-to-face interviews with three research questions and they include; 1) what is the relationship between coups and the Army? 2) Why is Technology important during Crises? 3) How are Crises 
beneficial? Stage 2 employed Brand24 analytical tool. It is an online text mining tool and previous studies have used it, for instance, (Bhattacharyya \& Neenu, 2021; Ilk \& Fan, 2020).

\subsection{Participants}

The participants include ten respondents from different fields of study. One student is from the department of political science, another one from international relations, one from information technology, three students from Civil engineering, another one from tourism management, two students from Mechatronics Engineering, and another one from electrical engineering. These participants speak and understand English language; hence, there is no need for a translator. This selection pattern allowed multiple sources of data. Also, using data from multiple sources of evidence can increase study rigor (Gatow, 2020), and assessing data from multiple sources to address rival explanations allows evidence-supported reporting results, at the same time increasing the reliability and validity of findings (Yin, 2014).

Stage 2 is a synthesis of gray literature and gray data (Adams, Hillier-Brown, Moore, Lake, Araujo-Soares, White, \& Summerbell, 2016). This is because today's unstructured data is mainly on the Web. Quite above $90 \%$ of the worlds' information is structurally on social websites such as Twitter, news, and blogs (Kim, Trimi, \& Chung, 2014), and they help in collecting data for this study using Brand24.com technique. Note that Grey and data literature are in electronic formats, and in print publications by industries, businesses, academia, and all levels of government whose aims are not for commercial interest and where publishing is not the main activity of the organization (Farace \& Schopfel, 2010: p. 1).

\subsection{Criteria for Sample Selection}

In stage 1, all participants must be students from the aforementioned fields of study. Combined knowledge from these departments is tangible enough to answer the research questions because the questions depend on the experiences from daily teachings and practical works in those departments. The selection of participants was possible through the snowball sampling technique because we do not know them individually i.e., by referral.

In stage 2, the data used must be terms that relate to political and technological crises and must be from the gray studies referenced in this study. Further, the following social media available such as twitter, forums, news, videos, podcasts, and blogs are suitable because they are common sources used by Brand24.com technique and previous studies have used these media categories to achieve satisfactory results, especially, studies that deal with global issues. I think therefore Pathak, Agarwal, Pandey, \& Rautaray, (2020) opined that social media platforms such as forums, blogs, and opinion sites generate vast amounts of data. Unstructured format characterized such data as opinions, emotions, and views about services, politics, and products, and serve as primary data that meet diverse search 
needs.

\subsection{Data Collection}

Stage 1 data was collected through face-to-face interview records with the permission of the participants. The interview lasted between 3 to 10 minutes. They were told that the interviews were freewill and anyone is free to quit at any stage of the interview.

Stage 2 data was collected from statements that supports and relates to the current topic, and were analyzed automatically using the web and social media monitoring tool (Brand24.com) with special attention to keywords and statements relating to this topic. Search terms depend on the database (Shrestha, Andersen, Neupane, Ghimire, Campbell, \& Kallestrup, 2020) of this analytical technique. Online-contents are very informative in producing sound results with easy access and do not allow researchers' bias that hinders respondents' opinions or wiliness of expression as with questionnaires (Gemzik-Salwach, 2020). Recall that previous studies have achieved satisfactory results using the Brand24.com tool, for instance, (Augustyniak, Rajda, Kajdanowicz, \& Bernaczyk, 2020; Bachmann, 2020; Pathak, Agarwal, Pandey, \& Rautaray, 2020; Lee, Buchanan, \& Yu, 2020).

\subsection{Data Analysis}

In stage 1, this study employed manual analysis because the sample size and transcripts are not too many. Also, the data saturation was at the 10th respondent. So it was easier to analyze manually compared to interviews with a large population. Further, manual analysis has its benefits. Normally, studies with bulky transcripts are not very suitable for manual analysis. Following the transcripts, codes were developed through an interpretive process of data comparison. i.e., going through the transcripts line by line to make sense of the writing and then grouping them into meaningful codes and then into categories, thereafter minimizing them into fewer themes that represent the ideas of the respondents without external interference/missing of words. Manual coding allows attaching meaningful attributes and researchers can engage in a range of analytical processes such as pattern detection and categorization (Wicks, 2017; Saldaña, 2021).

In stage 2, founded in 2011, Brand24.com is an analytical monitoring technique that uses social media and the web to screen search keywords and refine them for better output such as mentions, sources and then filters the results under negative and positive sentiments. Also, sentiment analysis scrutinizes people's opinions toward entities such as products, services, persons, and organizations present in the text (Pathak et al., 2020). So, to examine the positive spillovers of crises on persons, organizations, and destinations, the technique analyzed three search terms (keywords) for political and technological crises, found online for twelve months. For political crisis, two search terms; coup cleans our 
army, and crisis is beneficial was searched from August 2019 to August 2020 and analyzed and filtered under negative and positive sentiments. In the second search, one search term; technology saves were searched from November 2019 to November 2020 and filtered under negative and positive sentiments. Together, these three search terms were chosen because they are directly mentioned in the discussion paragraphs as quotes, sentences, and/statements (Table 1).

\section{Findings}

Figure 1(a) below presents the findings in stage 1 (face-to-face interview) under three themes developed from thirteen codes, both of which represent the ideas and opinions of the respondents. These findings answered the research questions posed in chapter one. The first theme is political factors and they include political relationships, political allies, political instability, and chances of success. Second theme is technological factors and they include the Importance of technology, learning applications, getting in touch, and information sharing. The third theme is experiential and expectation factors and they include present \& future solutions, resilience, learning from experience, land management, and benefits of crises.

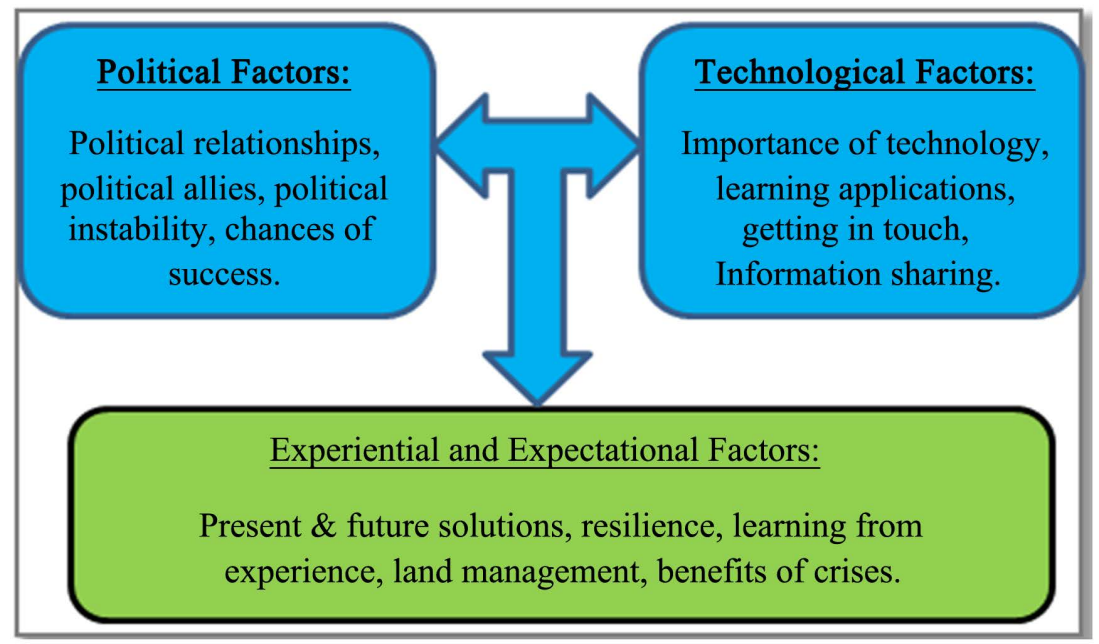

(a)

Project: Coups cleans our army

$$
\begin{gathered}
\text { Mentions: } \\
19546 \\
\text { Total } \\
5081 \\
\text { Positive } \\
3126 \\
\text { Negative }
\end{gathered}
$$

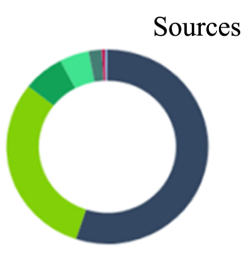

(b)

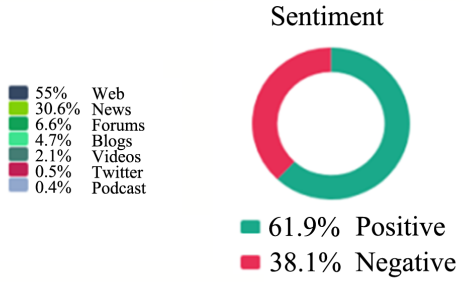

Figure 1. (a) Findings from stage 1 interviews; (b) Summary for coups cleans our army. Source: Auto generated from Brand24 tool. 
Table 1. Respondents' demography.

\begin{tabular}{cccccc}
\hline NO & Departments & Nationalities & Age & Sex & Language \\
\hline $\mathbf{1}$ & Political Science & Nigeria & 38 & Male & English \\
$\mathbf{2}$ & International Rel. & Nigeria & 29 & Male & English \\
$\mathbf{3}$ & Civil Engineering & Lebanon & 27 & Male & English \\
$\mathbf{4}$ & Civil Engineering & Lebanon & 24 & Male & English \\
$\mathbf{5}$ & Information Tech. & Nigeria & 30 & Male & English \\
$\mathbf{6}$ & Civil Engineering & Nigeria & 42 & Male & English \\
$\mathbf{7}$ & Tourism Mgmt. & Nigeria & 27 & Male & English \\
$\mathbf{8}$ & Mechatronics Engr. & Lebanon & 22 & Male & English \\
$\mathbf{9}$ & Mechatronics Engr. & Palestine & 22 & Male & English \\
$\mathbf{1 0}$ & Electrical Engr. & Nigeria & 23 & Male & English \\
\hline
\end{tabular}

Source: Author's design.

\section{Stage 1 Discussion}

\subsection{Political Factors}

\subsubsection{Political Relationships}

Some respondents opined that there is a political relationship between the coup and the Army. This relationship is that a coup cannot exist without the crisis, and with crisis Army will leverage on that to make a coup to topple the government. Recall, the statements and quotes below are written verbatim. The statement below supports this;

"First, we have to look at it this way; without the crisis, there will not be a coup, you understand. The army is the armed forces of the country, you understand. Their job is to defend the country. So during the crisis, for example during the civilian rule, if the civilian rulers are not doing well in a particular country, the Army may decide to take over through coup d'état. So with that, I will say, a coup cannot exist without the crisis and with crisis Army will leverage on that to make a coup to topple the government so they both intertwine ". (Respondent 1)

From the statement above, one can see that political crisis has the advantage for those that plotted a successful coup as it will benefit and satisfy their political ambitions.

\subsubsection{Political Allies}

It is good to note that politics operate with allies and interests. And I think most political ambitions are successful because of support from allies. Political allies may offer beneficial services through mutual relationships. The statement below supports this.

"Yeah, technology is important in crisis or without crisis. But let's talk about during crisis, technology helped during coups. During the crisis in Turkey, the 
president was not in the capital Ankara, So, he wants to reach his people to protest against the coup using an application in an iPhone with the help of Russia. And his people went out and protested against the coup". (Respondent 4)

From the above statement, one can see that the President of Turkey could achieve his ambition with the help of an iPhone application from his political ally-Russia. So, allies can help actualize positive spillovers for members during a political crisis.

\subsubsection{Political Instability}

Political instability is part of the crises faced by so many destinations globally. This type of crisis involves different persons and organizations. However, it is most common with Military regimes in challenging situations. The statement below supports this;

"Generally, Army is the one that embarks on the coup and many instances, especially in Africa and other third world countries the Armies have to embark on coups for several reasons, it could start from corruption, and ethnicity and all that, the Army can intervene. It happened in Cambodia, In the 1960s 70s, and 80 s it happened in Nigeria. It happened in Turkey in 2016. So most often than not, Armies are the ones who embark on coups and most of them are successful others are unsuccessful”. (Respondent 2)

The above statement shows that political instability relates to the Army/Military and they intervene because of bad governance or during external inversion by political rivalries.

\subsubsection{Chances of Success}

Coup d'état is a political weapon with two outcomes; successful or unsuccessful. But the chances of success are always higher with coups staged by the army than the civilians. The statements below support this:

"Well, the coup and the Army can be said to be the same body because the Army are the ones who carry out the coups. The coups are where the military takes over the government from the ruling party. So this is done by the civilians and the military. In most cases, the military is the one who instigates this course and the $\%$ of them being successful is about $95 \%$ while those by the civilians mostly are unsuccessful". (Respondent 3 ), also.

"Generally, the Army is the one that embarks on the coup and many instances especially in Africa and other third world countries where Armies have to embark on coups for several reasons, it could start from corruption, and ethnicity and all that, the Army can intervene, it happened in Cambodia, In the 1960s 70s, and 80s it happened in Nigeria. It happened in Turkey in 2016, so most often than not, Armies are the ones who embark on coups and most of them are successful others are unsuccessful”. (Respondents 2)

From the above statements, the army as a political organization has higher chances of staging a successful coup compared to civilians. And we associate them with coup as a type of crisis. Figure 1(b) above is the analytical summary 
of coups cleans our army. While Figure 2 is the graph for coup cleans our army. Both figures support the interview findings.

\subsection{Technological Factors}

\subsubsection{Importance of Technology}

Technology is very useful in life, and without it, a lot of problems will be difficult. The importance of technology cuts across limits. The statement below supports this.

"Yeah, technology is important in crisis or without crisis. But let's talk about during crisis. Technology helped during the coup in Turkey. The president was not in the capital, Ankara, So, he wants to reach his people to protest against the coup using an application in an iPhone with the help of Russia. And his people went out and protested against the coup". (Respondent 4)

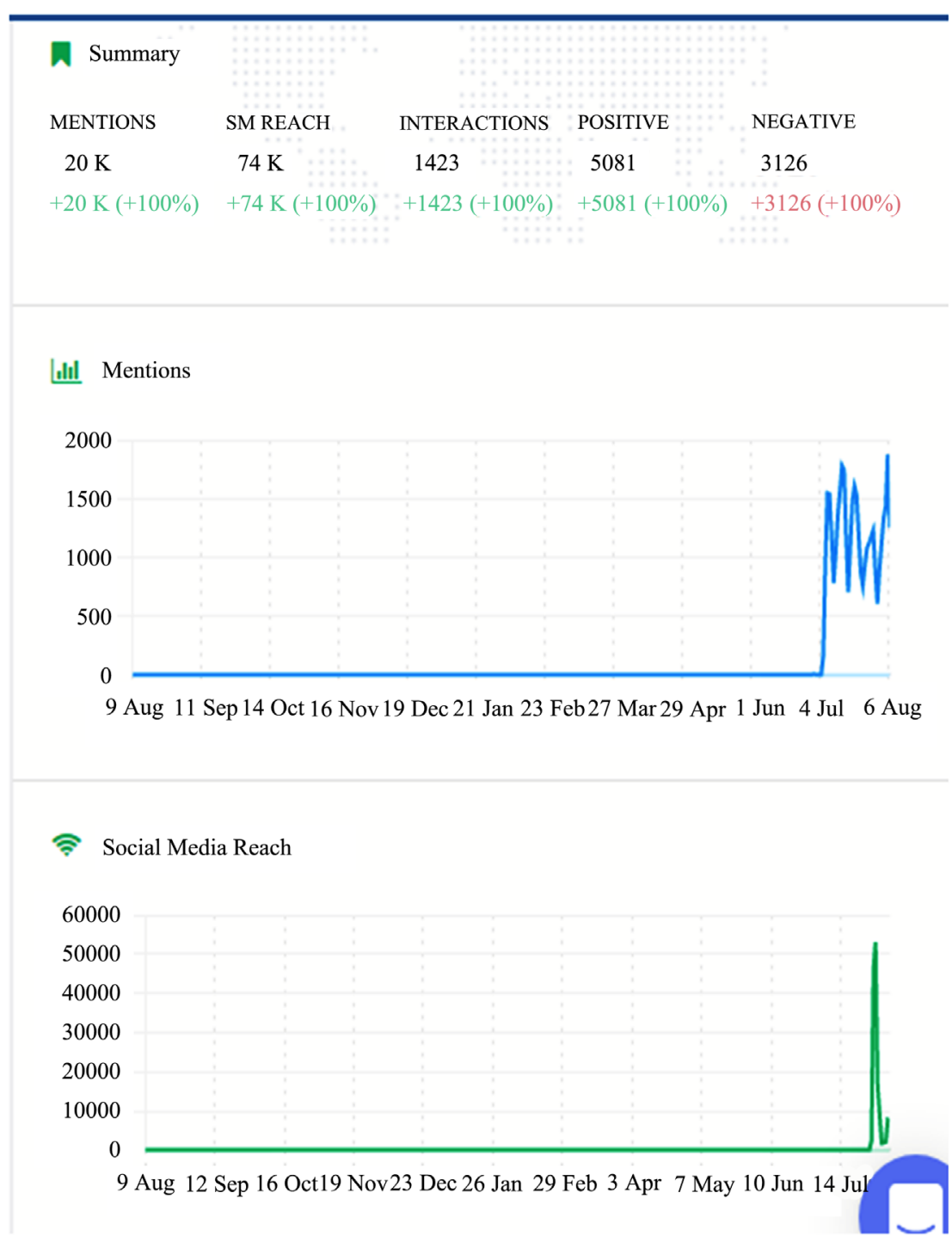

Figure 2. Graph for coups cleanse our Army. Source: Auto generated from Brand24.com tool. 
From the above statement, technology helps in diverse ways and can improve so many situations.

\subsubsection{Learning Applications}

The importance of technology cuts across diverse levels of life. It serves as an intervention, and as a tool for educating students. The statement below supports this.

"Well, technology is very important during a crisis. The best example is the Coronavirus (Covid-19). First, for education, with the help of technology and software programs like the team, zoom, online education is possible. Students use these applications to learn. So technology helps. If there is no technology, students will not have their education. So with these software applications, education continues. So there will be no education without these Technologies. Technology is very important in crises". (Respondent 6)

From the above statement, one can see that technological applications help in crises.

\subsubsection{Getting in Touch}

Unlike before, technology now improves the rate of information sharing. And people can now contact their fellows in distant places with ease. The statement below supports this:

"Well, technology is very important. So, back to my first example about the revolution that starts in my country in 2019, more people followed up the revolution, like me, I follow social media, I am always in touch. Even in my country, do you know what these politicians do to the civilians? So they go against the politicians. Also, you can use iPhone to call the police or the ambulance if something bad happens. Also, in Cyprus, about something that happened like snow and foul weather, people cannot go to Girne. So with the help of technology, we know of the foul weather in Girne so we did not go to Girne. So, technology gives us information about what is happening in other places". (Respondent 5)

From the above statement, technology helps in reaching out in times of need.

\subsubsection{Information Sharing}

"Information is key" they say. Persons, organizations, or destinations without information are like a lost zone because they will be stagnant. But with information, people can know what to do concerning any challenge. The statements below support this;

"As we know today, technology can decrease the influence of any crises on human daily life since it may alert you early about the occurrence of the crisis and may limit the damage of the crisis like the fire sensor we have in every house, if it sounds, everyone gets alert". (Respondent 10), also,

"It is very important because it helps to share information with the people and inform the people about crises and again on what to do next about the crisis. When there is a crisis in a destination, it videos it for people and to the entire 
world, it is very important. Ah, crises create benefits because if there is a crisis, we see whether a country for example I am from Nigeria. We have a crisis in the country right away. And the crisis we are having is because of corruption and some people said that the country does not need to disintegrate; some said the country needs a constitutional change. Some are saying we have to go back to the regional government. So from this point, some people are saying we don't need all these things, we just need change. So with help of crisis, we try to move from a bad constitution to a new constitution, then we try to balance everything. For example, with Covid-19, without the help of tech, doctors and nurses won't be able to share information that there is a crisis in Wuhan China. It was Prof. Leo. Who first inform the world that there is a crisis with the help of technology". (Respondent 1)

From the above statements, technology serves as an informational tool for people.

\subsection{Experiential and Exceptional Factors}

\subsubsection{Present and Future Solution}

We get solutions from experiences in daily crises. When you face a challenge, you will do your best to overcome it next time you will be familiar with it. The statements below support this:

"During world war ii, there was a virus outbreak like the current one but the scientists could not found vaccines for the virus then. Based on this crisis experience, they are still producing and distributing it to countries. In my point of view, because it will push you to think of the future and base on that knowledge and the experience, you will think of how to solve the future problem". (Respondent 4), also,

"Crises create benefits for example after a crisis, people and government learn lessons from the crises and ensure the crises do not occur in the future". (Respondent 2), also,

"Okay, my friend, as you know technology can decrease if you do not have crises because you use the technology to help human beings to have experience on how to deal with a crisis. After one experience, next time when he sees it next time, you will have experience and they can do something if they know there will be a crisis you know". (Respondent 8 )

These statements above confirm that experience helps to provide solutions for the future.

\subsubsection{Resilience}

Resilience is the ability to recover fast from any hard events. In life, persons, organizations, and destinations encounter difficulties, but what proves that such an entity is resilient is the capacity to come back into shape. The statements below support this;

"Yes, I will start with an example of what happened in Hiroshima, Japan after the atomic bomb, 10 years after the explosion, it was a large crisis. So they be- 
came experts in technology globally. Maybe if they did not have this crisis, they will not be at this place at this high rank of technology and education because when you fall, you get up and you become stronger. Another example with a student, when he gets a nasty mark, he will study well for the final. With companies like iPhone, they once made a mistake, and they fixed it and became better than before, they get benefits from these crises. Also, Istanbul 30 years ago was like a big container for garbage, but because of this crisis, they made a solution and it was very effective. So now Istanbul is the most popular city in the world for tourism”. (Respondent 7), also,

"As I mentioned before, you know you can improve any breakdown or electrical problem, if you have the experience you will improve it and put it in your mind and it will not happen again". (Respondent 9), also,

"As we know today, technology can decrease the influence of any crises on human daily life since it may alert you early about the occurrence of the crisis and may limit the damage of the crisis like the fire sensor we have in every house, if it sounds, everyone gets alert”. (Respondent 10)

The statements above show that technology can help us bounce back or get better during and after any experience of crisis.

\subsubsection{Learning from Experience}

There is a common saying that experience is the best teacher. The statement below supports this;

"As I mentioned before, you know you can improve any breakdown or electrical problem, if you have the experience you will improve it and put it in your mind and it will not happen again" (Respondent 9)

As seen above, each day's experience guides us with the knowledge of tomorrow's strength.

\subsubsection{Land Management}

Human beings learn from daily crises. And we regard crises as a source of knowledge in preventing future hazards. The statement below supports this;

"Well, so we have an example in my language that says; one does not learn until he is hot. So you will learn from your mistakes as what happened in China. Because of strong wind, many buildings damaged. So building designs in China, for example, the Shanghai hall china is twisted, in that case, the wind will not crush the building, and the design will reduce the damage, and because in china, the population is high so they create a solution for this crisis because if they continue with horizontal building, they will not get enough space for the people to live, so they started vertical designs because it takes less space, and can carry more people, like one village living in one building". (Respondent 5)

From the above statement, knowledge transfers through these experiences.

\subsubsection{Benefits of Crises}

Both individuals and governments face different crises in their daily lives. Although crises relate to negative spillovers, however, after each crisis, there are 
different lessons learned from them. The statements below support this;

"Crises create benefits for example after a crisis people and government learn lessons from the crises and ensure the crises do not occur in the future". (Respondent 2), also,

"It has many benefits, it increases human benefits like when next you face a crisis, you know about it before, and you can finish the crises quickly not like the previous one". (Respondent 8 )

From the above statement, it looks as if we need crises in our daily lives since it goes with some moral lessons. Figure 3 below is the summary graph for technology saves. Also, Figure 4 and Figure 5 below are graphs for crisis is beneficial and technology saves. Both graphs support the quotes/statements from the respondents above (Table 2).

\subsubsection{Stage 2 Discussions}

Before discussing the scenarios under political crisis, recall the quote by Robert Tew (n.d.) that:

"The struggle you're in today is developing the strength you need tomorrow". Usually, crisis leaves people struggling, but practically, whatever struggle we find ourselves in today prepares us with the strength we need to face tomorrow. To fill the literature on positive spillover of crises on persons, organizations, and destinations, it is necessary to recall the statements from introductory and literature review sections while comparing the keywords for analysis. So, statements that relate to the study's argument were retracted and reflected on, ensuring that they support the claim. The following are search terms retracted from the above statements for analysis;

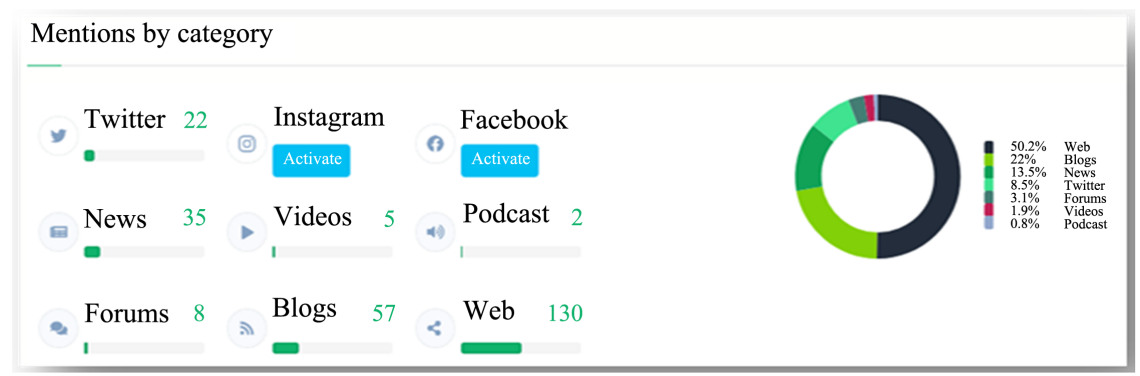

Figure 3. Summary for technology saves.

Table 2. Searched terms (Keywords).

\begin{tabular}{cccccc}
\hline NO. & Search Terms & Worldwide & $\begin{array}{c}\text { Past 12 } \\
\text { months }\end{array}$ & Categories & $\begin{array}{c}\text { Search } \\
\text { Sources }\end{array}$ \\
\hline $\mathbf{1}$ & $\begin{array}{c}\text { Coups clean } \\
\text { our Army }\end{array}$ & Worldwide & Past twelve Months & All categories & Web \\
\hline $\mathbf{3}$ & $\begin{array}{c}\text { Crisis is } \\
\text { beneficial } \\
\text { Technology } \\
\text { saves }\end{array}$ & Worldwide & Past twelve Months & All categories & Podcast \\
\hline
\end{tabular}




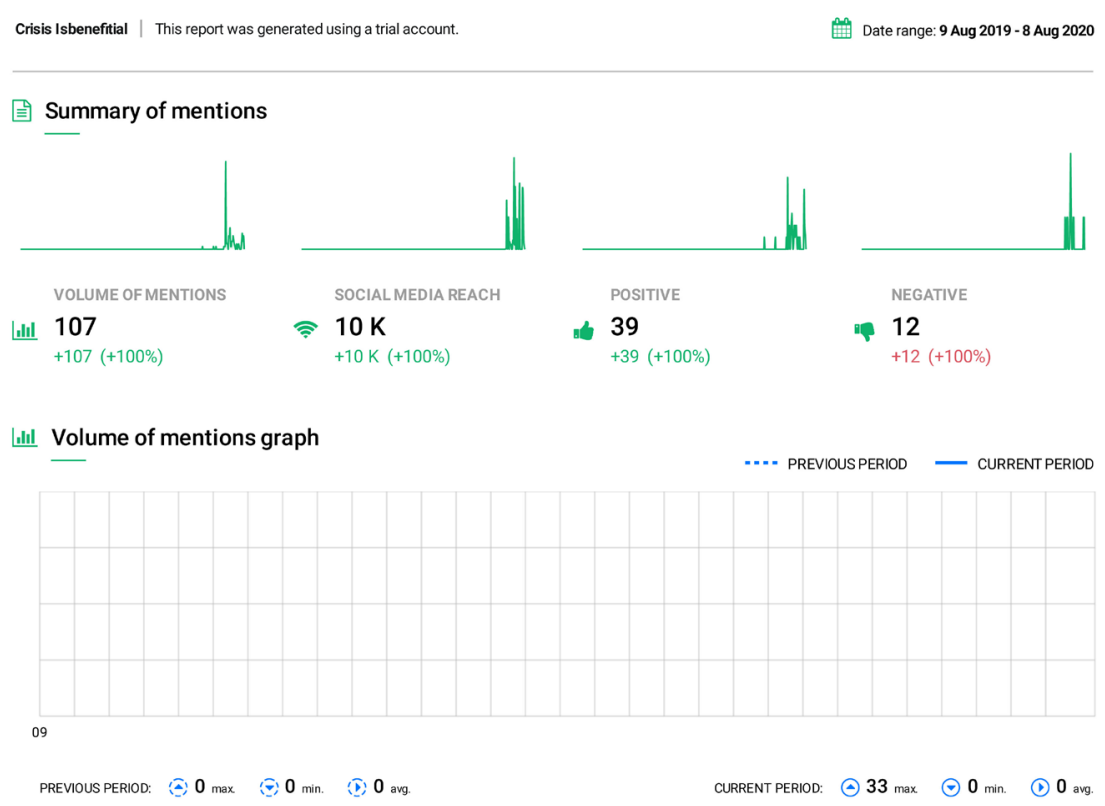

(a)

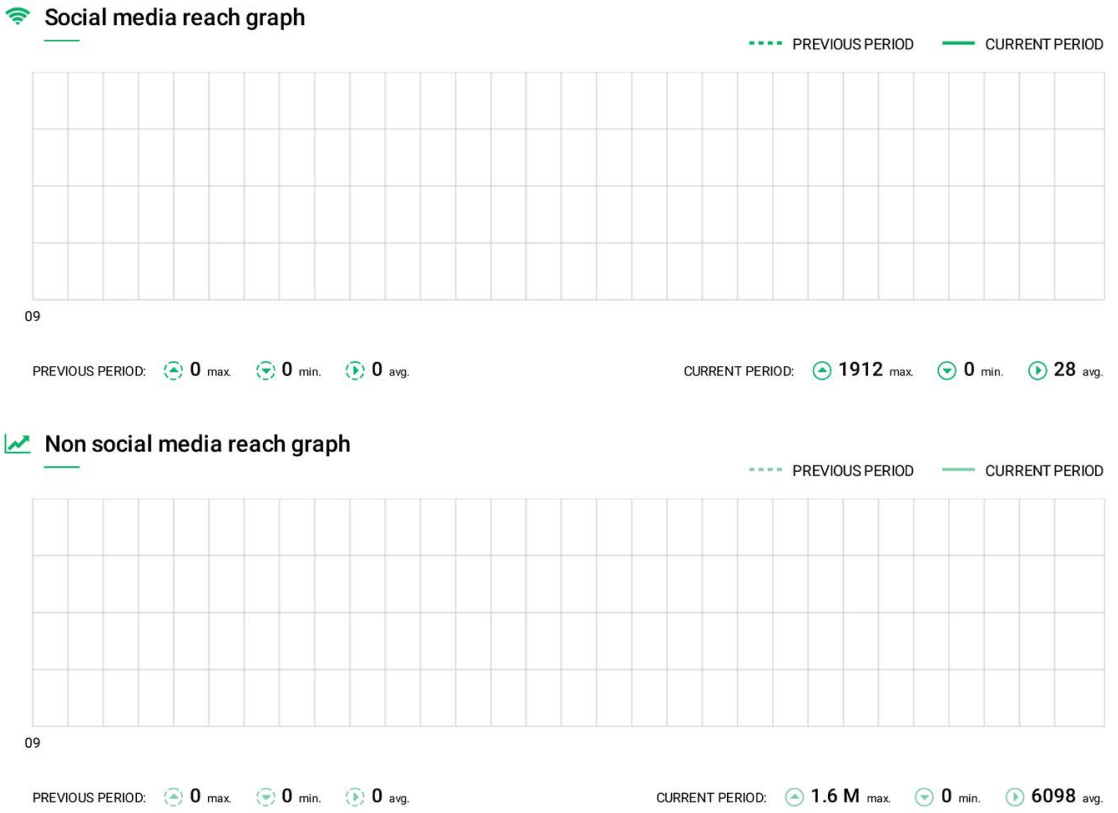

(b)

Figure 4. (a) Graphs for crisis is beneficial; (b) Graph for crisis is beneficial.

"This uprising is a gift from God to us because this will be a reason to cleanse our army”, (Movement, Erdoğan, Yıldırım, Akar, Dündar, \& Gülen, 2016-17). In the first scenario, the selected search term is; "coup cleans our army". And the result of the analysis was positive with 5081 positive and 3126 negative mentions (Figure 2 above is graph for coups cleans our army), it supports that crises have positive spillovers.

It is also worth noting that; while post-coup d'état decreases respect for physical integrity rights when non-democratic regimes overthrow democratic regimes 
Social Media Reach

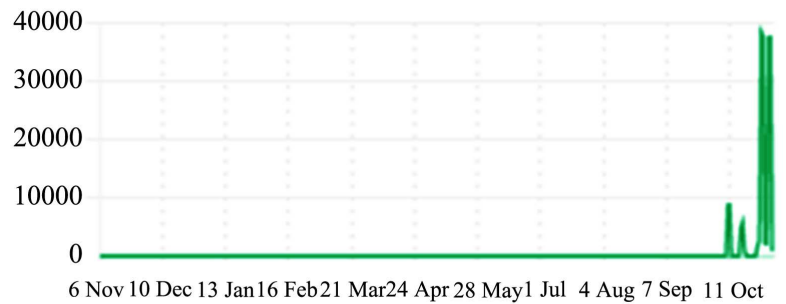

(a)

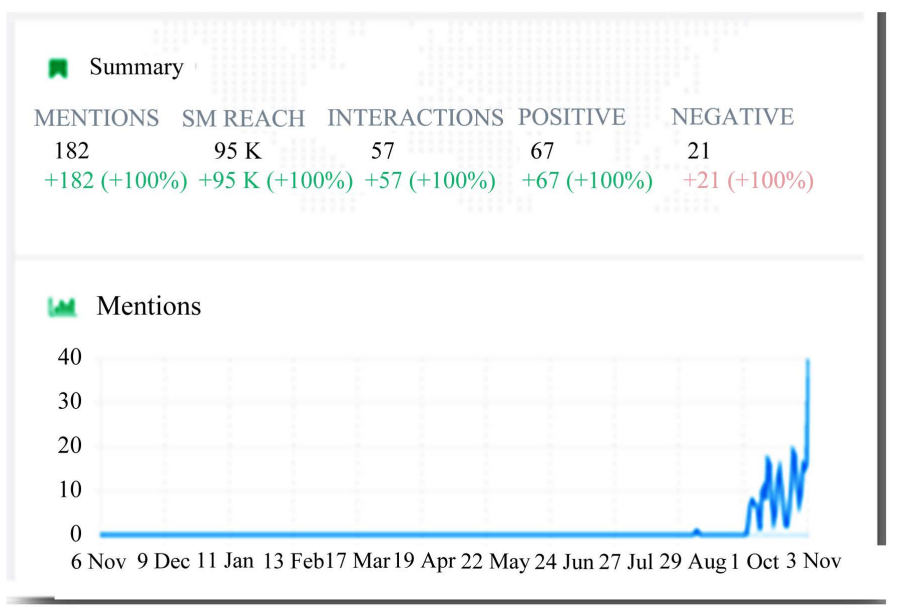

(b)

Figure 5. (a) Graph for technology saves; (b) Graph for technology saves.

through coup d'état, it increases respect for physical integrity rights ordinarily. The statement below supports this:

“The unelected guardians aligned with the military's support for the Republic's founding principles would thus be entrusted with a liberal standing doctrine to clean up what the military viewed as the mess that self-seeking politicians would inevitably create" (Varol, 2012). This crisis of abuse of power can lead to one's personal, political, families or social class benefits, (Ebegbulem, 2020). Hence, the search term; "clean-up mess" is in line with the above search term; "Coup cleanse our army". Both support that; political crisis has positive spillovers.

Further, the revolution and hybrid war with the Russian federation in 2013 brought along deteriorated consequences in many basic economic indicators. Still, it speeded social reforms particularly, the higher education system which hosted foreign students' training from 185 higher education institutions in the 2015/2016 academic year to 228 higher education institutions in the 2016/2017 academic year (Shevchenko, 2019). The keyword; "speeded social reforms" support the search term; "cleans our army" because they all talk of restoring a shattered state of normality. Both scenarios suggest that political crises have positive spillovers.

In the second scenario, to verify the findings of the first search on political 
crisis using the search term; "coups cleans our army", another politically related term; crisis is beneficial was chosen and searched for. The result was also positive; supporting the claim that political crisis has positive spillovers. From the results in the graph above; there are 39 positive and 12 negative sentiments (Figure 4(a)).

In the second scenario (technological crisis), note that the technological revolution in the current day has created a quest for robust and resilient experts and tech-savvy search engines, unlike the traditional search technologies, artificial intelligence technologies now help tour operators and other travel agencies solve the crisis of duration, selection \& analyzes of tourist's routes by reducing the time of selection and analyzing large volumes of data to fulfill customer orders as a competitive advantage against the traditional engines (Kazak et al., 2020). Hence the searched term is; technology saves and the search result supports the claim that political crises have positive spillovers with 67 positive and 21 negative sentiments (Figure 5(b)). These three findings are all positive, and thus; answers the three research questions posed in chapter one.

Also, according to Nemkumar, Head-Institutional Equities, IIFL; "the ill-fated coronavirus outbreak in china has offered India with an opening to receive the 'Make in India' program". It means that the technological shutdown in China which was caused by the coronavirus still has the potential for positive spillovers to benefit other countries such as India.

Managerially, there are instances from service sectors where recovering failed services can create more goodwill than if things had gone smoothly in the first place and through this procedure, recovery encounters would mean an opportunity for service providers to increase customer retention (Bagherzadeh et al., 2020), that is resilience spillover. The next quote supports this argument/idea thus;

"A good recovery encounter can turn angry and frustrated customers into loyal ones and can create more goodwill than if things had gone smoothly in the first place" (Hart et al., 1990).

Practically, it is important for persons, organizations, and destinations, to be sensitive enough to identify any brief opportunities amidst crises and use them properly; believing that the struggle they are in today develops the strength for tomorrow. These studies call for proper care to identify opportunities for positive spillovers. And stage 1 and stage 2 findings have similarities and therefore support the study's argument.

\subsection{Limitations and Future Study}

Conventionally, this study is not without limitations, and so the absence of previous studies on the topic is the first limitation. While the lack of the previous study created the need for the current research, it also stands as a limitation and prompts the use of gray and data literature. So, this lays a foundation for future researchers. Future studies can build from this foundation to examine the positive spillovers of political and technological crises in educational institutions and 
airline industries.

Further, the nature of this study gave no room for pilot study. Therefore, this limitation calls for future researchers to conduct pretest in this field. Also, future researchers should improve participants' samples by involving both male and females.

Truly, no one prays for crises, however, crises are inevitable, but some types of crises occur suddenly. They often happen in slight and silent forms without signals. It is difficult to pay attention to all that happens around us as humans, hence limiting the chances to identify the positive spillovers. So, organizations should pay attention to identify and use potential benefits accruing from day-today crises for tomorrow's strength.

Further, it is necessary for managers to not only pay attention to crises but also to create environments that are at least 60 percent free from crises by ensuring that equipment in their workplaces are sound and that they maintain rules and regulations that supports workforce diversity rooted in sound ethics and investing more in research and development to capture signals for new competency. These findings are necessary for every sector especially, the political economy of development and communication, tourism management regarding tour operations and destination management, and marketing management regarding political, economic, social, and technological (PEST) management.

\section{Conclusion}

Recall that this study aims to fill the literature on the positive spillovers of crises on persons, organizations, and destinations. Although interviews helped in achieving the stage 1 findings, however, it is good to remark that this type of topic would have been difficult to achieve but for the emergence of sentimental analytical technique (Brand24.com) which aided the mining and analyzing the study's mentions and sentiments i.e., Mining and analyzing large volume of data in a short time (Leung, 2019). This shows the importance of social media analytical tools, particularly on data collection and analysis, great thanks to social media.

Both findings support the study's arguments, first, from stage 1, three themes: political, technological, and experiential \& expectation factors emerged from 13 codes. The political factors show that politically related crises can positively spillover for resilience. Technological crisis findings show that the breakdown of technological appliance can lead to improvement, innovation, create marketing, and upgrade to a standard system, while experiential \& expectation factors show that when persons, organizations, and destinations encounter crises; they tend to breakdown, but those that survive emerge resiliently. This supports the quote; "the struggle you're in today is developing the strength you need tomorrow".

In stage 2, the sentiment analytical tool Brand24.com analyzed three keywords. Findings revealed 19546 internet users' opinions shown as mentions, 3126 were negative sentiments (Figure 1(b)) which show that though crises have negative effects, however, it also has potentials for positive spillovers which may some- 
times outweigh the negative effects but because the negative side of crisis is more emphasized, the positive side might not be obvious if not thoroughly examined. It supports this by 5081 positive and 3126 negative (Figure 2), 39 positive and 12 negatives (Figure $4(\mathrm{a})$ ), and 67 positive and 21 negative sentiments, respectively (Figure 5(b)). In sum, both stage $1 \& 2$ findings support that political and technological crises have positive spillovers on persons, organizations, and destinations irrespective of contexts, and subjects across Covid-19 crisis.

\section{Acknowledgements}

The author would like to thank the Almighty God, his parents, teachers, and friends. Without them, I could never have fulfilled my dreams.

\section{Data Availability Statement}

Data used in stage 1 is on request while stage 2 data is auto-generated based on the account created with Brand24.com.

\section{Conflicts of Interest}

The author declares no potential conflicts of interest of any kind regarding the publication of this paper.

\section{Funding}

There is no sponsorship of any kind to this study. And external files are supporting this main document.

\section{References}

Adams, J., Hillier-Brown, F. C., Moore, H. J., Lake, A. A., Araujo-Soares, V., White, M. \& Summerbell, C. (2016). Searching and Synthesizing "Gray Literature and Gray Information" in Public Health: Critical Reflections on Three Case Studies. Systematic Reviews, 5, Article No. 164. https://doi.org/10.1186/s13643-016-0337-y

Adisonmez, U. C., \& Onursal, R. (2020). Governing Anxiety, Trauma, and Crisis: The Political Discourse on Ontological (In)Security after the July 15 Coup Attempt in Turkey. Middle East Critique, 29, 291-306. https://doi.org/10.1080/19436149.2020.1770445

Ahmed, D., Buheji, M., \& Fardan, S. M. (2020). Re-Emphasizing the Future Family Role in the "Care Economy" as a Result of Covid-19 Pandemic Spillovers. American Journal of Economics, 10, 332-338. https://doi.org/10.5923/j.economics.20201006.03

Augustyniak, Ł., Rajda, K., Kajdanowicz, T., \& Bernaczyk, M. (2020). Political Advertising Dataset: The Use Case of the Polish 2020 Presidential Elections. arXiv preprint arXiv:2006.10207. https://doi.org/10.18653/v1/2020.winlp-1.28

Australian Seasonal Bushfire Outlook: December 2020-February 2021. https://www.preventionweb.net/publications/view/74958

Bachmann, P. (2020). Public Marketing: Case of Self-Governing Regions' Brands in Online Environment. https://doi.org/10.36689/uhk/hed/2020-01-003

Bagherzadeh, R., Rawal, M., Wei, S., \& Torres, J. L. S. (2020). The Journey from Customer Participation in Service Failure to Co-Creation in Service Recovery. Journal of Retailing and Consumer Services, 54, Article ID: 102058. 
https://doi.org/10.1016/j.jretconser.2020.102058

Balland, P. A., Rigby, D., \& Boschma, R. (2015). The Technological Resilience of US Cities. Cambridge Journal of Regions, Economy, and Society, 8, 167-184.

https://doi.org/10.1093/cjres/rsv007

Barbhuiya, M. R., \& Chatterjee, D. (2020). Vulnerability and Resilience of the Tourism Sector in India: Effects of Natural Disasters and Internal Conflict. Tourism Management Perspectives, 33, Article ID: 100616. https://doi.org/10.1016/j.tmp.2019.100616

Basch, J. M., Melchers, K. G., Kurz, A., Krieger, M., \& Miller, L. (2020). It Takes More Than a Good Camera: Which Factors Contribute to Differences Between Face-to-Face Interviews and Videoconference Interviews Regarding Performance Ratings and Interviewee Perceptions? Journal of Business and Psychology, 1-20.

https://doi.org/10.1007/s10869-020-09714-3

Besim, M., \& Mullen, F. (2009). Cyprus in the Global Financial Crisis: How Lack of Banking Sophistication Proved an Advantage. South European Society and Politics, 14, 87-101. https://doi.org/10.1080/13608740902995877

Bhattacharyya, S. S., \& Neenu, N. (2021). Active Social Listening and Its Impact on Firm Strategies: Study of Indian Context. In P. Ordóñez de Pablos, \& M. Lytras (Eds.), Global Challenges and Strategic Disruptors in Asian Businesses and Economies (pp. 95-114). Hershey, PA: IGI Global. https://doi.org/10.4018/978-1-7998-4787-8.ch006

Bieling, H. J., \& Guntrum, S. (2020). European Crisis Management and the Politics of Financialization. In S. Wöhl, E. Springler, M. Pachel, \& B. Zeilinger (Eds.), The State of the European Union (pp. 133-154). Wiesbaden: Springer VS.

https://doi.org/10.1007/978-3-658-25419-3 6

Bjørnskov, C., \& Pfaff, K. (2018). Differences Matter: The Effect of Coup Types on Physical Integrity Rights. https://doi.org/10.2139/ssrn.3295281

Blazek, J., Hejnova, T., \& Rada, H. (2020). The Impacts of the Global Economic Crisis and Its Aftermath on the Banking Center of Europe. European Urban and Regional Studies, 27, 35-49. https://doi.org/10.1177/0969776418807240

Bozorgi-Amiri, A., Jalilibal, Z., \& Hahi Yakhchali, S. (2020). Balancing Construction Projects by Considering Resilience Factors in the Crisis. Journal of Industrial and Systems Engineering, 12, 100-109.

Burden, A. (2020). The History of Crises and Crisis Management in Anesthesia: Prevention, Detection, and Recovery. International Anesthesiology Clinics, 58, 2-6. https://doi.org/10.1097/AIA.0000000000000258

Duddy, P. (2015). Political Crisis in Venezuela. Council on Foreign Relations.

Ebegbulem, J. C. (2020). The Impacts of Political Corruption on Democratic Consolidation and the Electoral Process in Nigeria. Academicus International Scientific Journal, 21, $38-45$.

Eppel, S., \& Raftopoulos, B. (2008, December). Political Crisis, Mediation, and the Prospects for Transitional Justice in Zimbabwe. Solidarity Peace Trust for the SITO, Idasa Meeting on "Transitional Justice Options in Zimbabwe", Pretoria, Vol. 24.

Eranga, I. O. E. (2020). COVID-19 Pandemic in Nigeria: Palliative Measures and the Politics of Vulnerability. International Journal of Maternal and Child Health and AIDS, 9, 220-222. https://doi.org/10.21106/ijma.394

Fang, G., Chan, P. W. K., \& Kalogeropoulos, P. (2020). Social Support and Academic Achievement of Chinese Low-Income Children: A Mediation Effect of Academic Resilience. International Journal of Psychological Research, 13, 19-28.

https://doi.org/10.21500/20112084.4480 
Farace, D., \& Schöpfel, J. (2010). Grey Literature in Library and Information Studies. Munich: K. G. Saur. https://doi.org/10.1515/9783598441493

Gatow, R. S. (2020). The Use of Triangulation in Qualitative Studies Employing Elite Interviews. Qualitative Research, 20, 160-173. https://doi.org/10.1177/1468794119830077

Gemzik-Salwach, A. (2020). Institutional Analysis of Banks and Personal Loan Companies: Lesson from Poland. Journal of Economic Issues, 54, 142-163. https://doi.org/10.1080/00213624.2020.1720570

Giwa, S., Broderick, A., \& Omar, S. (2018). From Simplicity to Complexity: An Exploration of Emerging Lifestyles, Consumer Perceptions, and Response to Location Based Services. Copyright Statement, 5.

Harrison, M. K. (1965). Lindemann's Crisis Theory and Dabrowski's Positive Disintegration Theory-A Comparative Analysis. Perspectives in Psychiatric Care, 3, 8-13. https://doi.org/10.1111/j.1744-6163.1965.tb01446.x

Hart, C. W., Heskett, J. L., \& Sasser Jr., W. E. (1990). The Profitable art of Service Recovery. Harvard Business Review, 68, 148-156.

Herbert, R. J., Ross, K., Whetter, T., \& Bone, J. (2020). Maintaining Ecological Resilience on a Regional Scale: Coastal Saline Lagoons in a Northern European Marine Protected Area. In J. Humphreys, \& R. W. E. Clark (Eds.), Marine Protected Areas (pp. 631-647). Amsterdam: Elsevier. https://doi.org/10.1016/B978-0-08-102698-4.00032-0

Hooghe, M. (2012). The Political Crisis in Belgium (2007-2011): A Federal System without Federal Loyalty. Representation, 48, 131-138.

https://doi.org/10.1080/00344893.2012.653250

Hunt, E. K. (2020). Esther and Mordecai: Emergent Team Leadership and Resilience in Crisis. In B. Winston (Ed.), Leadership Growth through Crisis (pp. 121-140). Cham: Palgrave Macmillan. https://doi.org/10.1007/978-3-030-25439-1 8

Iborra, M., Safón, V., \& Dolz, C. (2020). The Role of Family Ownership in Survival and Bouncing Back: Good and Bad News? In C. Camisón, \& T. González (Eds.), Competitiveness, Organizational Management, and Governance in Family Firms (pp. 261-282). Hershey, PA: IGI Global. https://doi.org/10.4018/978-1-7998-1655-3.ch011

Ilk, N., \& Fan, S. (2020). Combining Textual Cues with Social Clues: Utilizing Social Features to Improve Sentiment Analysis in Social Media. Decision Sciences. https://doi.org/10.1111/deci.12490

Itoh, M. (2018). Wildlife in the Exclusion Zone in Chernobyl. In Animals and the Fukushima Nuclear Disaster (pp. 177-187). Cham: Palgrave Macmillan. https://doi.org/10.1007/978-3-319-70757-0 11

Jalala, S. S., Latifoğlu, G., \& Uzunboylu, H. (2020). Strength-Based Approach for Building Resilience in School Children: The Case of Gaza. Anales de Psicología/Annals of Psychology, 36, 1-11. https://doi.org/10.6018/analesps.343501

Karras, E., Arriola, N., McCarten, J. M., Britton, P. C., Besterman-Dahan, K., \& Stecker, T. A. (2020). Veteran Perspectives of Barriers and Facilitators to Campaigns Promoting Help-Seeking during Crisis. Community Mental Health Journal, 1-7. https://doi.org/10.1007/s10597-020-00729-x

Karunathilake, K. (2020). Positive and Negative Impacts of COVID-19, an Analysis with Special Reference to Challenges on the Supply Chain in South Asian Countries. Journal of Social and Economic Development, 1-14. https://doi.org/10.1007/s40847-020-00107-z

Kayaman, R., \& Arasli, H. (2007). Customer Based Brand Equity: Evidence from the Hotel Industry. Managing Service Quality: An International Journal, 17, 92-109. 
https://doi.org/10.1108/09604520710720692

Kayaman, R., \& Armutlu, C. E. (2003). Postmodern tüketici davranışının pazar bölümleme kavramına etkileri: Postmodern klanlar. Gazi Üniversitesi Ticaret ve Turizm Eğitim Fakültesi Dergisi, No. 1, 133-144.

Kazak, A. N., Chetyrbok, P. V., \& Oleinikov, N. N. (2020). Artificial Intelligence in the Tourism Sphere. IOP Conference Series: Earth and Environmental Science, 421, Article ID: 042020. https://doi.org/10.1088/1755-1315/421/4/042020

Kazakov, S., \& Oyner, O. (2021). Wellness Tourism: A Perspective Article. Tourism Review, 76, 58-63. https://doi.org/10.1108/TR-05-2019-0154

Keating, A., \& Hanger-Kopp, S. (2020). Practitioner Perspectives of Disaster Resilience in International Development. International Journal of Disaster Risk Reduction, 42, Article ID: 101355. https://doi.org/10.1016/j.ijdrr.2019.101355

Khantimirov, D., Karande, K., \& Ford, J. (2020). Dissatisfaction after Service Failures as a Realized Transaction Risk: Customer Opportunism as a Function of External and Internal Rewards. Journal of Retailing and Consumer Services, 52, Article ID: 101896. https://doi.org/10.1016/j.jretconser.2019.101896

Kim, G. H., Trimi, S., \& Chung, J. H. (2014). Big-Data Applications in the Government Sector. Communications of the ACM, 57, 78-85. https://doi.org/10.1145/2500873

Kondracki, N. L., Wellman, N. S., \& Amundson, D. R. (2002). Content Analysis: Review of Methods and Their Applications in Nutrition Education. Journal of Nutrition Education and Behavior, 34, 224-230. https://doi.org/10.1016/S1499-4046(06)60097-3

Larcos, G., Prgomet, M., Georgiou, A., \& Westbrook, J. (2017). A Work Observation Study of Nuclear Medicine Technologists: Interruptions, Resilience, and Implications for Patient Safety. BMJ Quality \& Safety, 26, 466-474.

https://doi.org/10.1136/bmjqs-2016-005846

Latif, E. (2015). The Relationship between Immigration and Unemployment: Panel Data Evidence from Canada. Economic Modelling, 50, 162-167. https://doi.org/10.1016/j.econmod.2015.06.013

Leandros, N., \& Papadopoulou, L. (2020). Strategic Business Models in Times of Transformational Change and Crisis: A New Typology for Sustainable Media. Journal of Media Management and Entrepreneurship (JMME), 2, 28-41. https://doi.org/10.4018/JMME.2020010102

Lee, N., Buchanan, K., \& Yu, M. (2020). Each Post Matters: A Content Analysis of \#Mental Health Images on Instagram. Journal of Visual Communication in Medicine, 43, 128 138. https://doi.org/10.1080/17453054.2020.1781535

Lemon, L. L., \& Hayes, J. (2020). Enhancing Trustworthiness of Qualitative Findings: Using Leximancer for Qualitative Data Analysis Triangulation. The Qualitative Report, 25, 604614. https://doi.org/10.46743/2160-3715/2020.4222

Leung C. K. S. (2019). Big Data Analysis and Mining. In M. Khosrow-Pour, \& D. B. A. (Eds.), Advanced Methodologies and Technologies in Network Architecture, Mobile Computing, and Data Analytics (pp. 15-27). Hershey, PA: IGI Global. https://doi.org/10.4018/978-1-5225-7598-6.ch002

Li, X., Wu, S., Li, X., Yuan, H., \& Zhao, D. (2020). Particle Swarm Optimization-Support Vector Machine Model for Machinery Fault Diagnoses in High-Voltage Circuit Breakers. Chinese Journal of Mechanical Engineering, 33, Article No. 6. https://doi.org/10.1186/s10033-019-0428-5

Malloy, T., \& Schwartz, D. (2020). Biden Crushes Sanders in a Democratic Race; Quinnipiac University National Poll Finds More Disapproval of Trump's Response to Coronavirus. Hamden, CT: Quinnipiac University Poll. 
https://poll.Qu.edu/national/release-detail

Martín, H., Herrero, A., \& de los Salmones, M. M. G. (2019). An Integrative Model of Destination Brand Equity and Tourist Satisfaction. Current Issues in Tourism, 22, 1992-2013. https://doi.org/10.1080/13683500.2018.1428286

McQuilken, L., Robertson, N., Abbas, G., \& Polonsky, M. (2020). Frontline Health Professionals' Perceptions of Their Adaptive Competencies in Service Recovery. Journal of Strategic Marketing, 28, 70-94. https://doi.org/10.1080/0965254X.2018.1511630

Milstein, B. (2015). Thinking Politically about Crisis: A Pragmatist Perspective. European Journal of Political Theory, 14, 141-160. https://doi.org/10.1177/1474885114546138

Mohajan, H. K. (2018). Qualitative Research Methodology in Social Sciences and Related Subjects. Journal of Economic Development, Environment, and People, 7, 23-48. https://doi.org/10.26458/jedep.v7i1.571

Mollick, A. V., \& Assefa, T. A. (2013). US Stock Returns and Oil Prices: The Tale from Daily Data and the 2008-2009 Financial Crisis. Energy Economics, 36, 1-18. https://doi.org/10.1016/j.eneco.2012.11.021

Morris, A. M., \& Diaz, L. (2020). Reimagining Housing: Affordability Crisis and Its Role in Disaster Resilience and Recovery. In S. Laska (Ed.), Louisiana's Response to Extreme Weather (pp. 241-259). Cham: Springer. https://doi.org/10.1007/978-3-030-27205-0 9

Movement, G., Erdoğan, R. T., Yıldırım, B., Akar, H., Dündar, Ü. \& Gülen, F. (2016-17). Purges in Turkey-The Complete Information and Online Sale with Free Shipping.

Nunes, F., \& Melo, C. R. (2017). Impeachment, Political Crisis and Democracy in Brazil. Revista de Ciencia Política, 37, 281-304. https://doi.org/10.4067/s0718-090x2017000200281

Odeyemi, J. O. (2014). A Political History of Nigeria and the Crisis of Ethnicity in Nation-Building. International Journal of Developing Societies, 3, 1-12. https://doi.org/10.11634/216817831302459

Ouyang, Z., Yao, C. N., \& Hu, X. (2020). Crisis Spillover of Corporate Environmental Misconducts: The Roles of Perceived Similarity, Familiarity, and Corporate Environmental Responsibility in Determining the Impact on Oppositional Behavioral Intention. Business Strategy and the Environment, 29, 1797-1808.

https://doi.org/10.1002/bse.2474

Özdemir, L., \& Balkan, M. O. (2010). The Positive and Negative Effects of Crisis on Organizations: An Application.

Pal, I., von Meding, J., Shrestha, S., Ahmed, I., \& Gajendran, T. (Eds.) (2020). An Interdisciplinary Approach for Disaster Resilience and Sustainability. Berlin: Springer. https://doi.org/10.1007/978-981-32-9527-8

Papadopoulos, Y. (2020). Eurozone Crisis Management and the Changing Nature of the Democratic Deficit in the European Union. In R. Careja, P. Emmenegger, \& N. Giger (Eds.), The European Social Model under Pressure (pp. 567-581). Wiesbaden: Springer VS. https://doi.org/10.1007/978-3-658-27043-8 32

Parker, D. J. (2020). Disaster Resilience-A Challenged Science. Environmental Hazards, 19, 1-9.

Pathak, A. R., Agarwal, B., Pandey, M., \& Rautaray, S. (2020). Application of Deep Learning Approaches for Sentiment Analysis. In B. Agarwal, R. Nayak, N. Mittal, \& S. Patnaik (Eds.), Deep Learning-Based Approaches for Sentiment Analysis (pp. 1-31). Singapore: Springer. https://doi.org/10.1007/978-981-15-1216-2_1

Powell, J., Chacha, M., \& Smith, G. E. (2019). Failed Coups, Democratization, and Authoritarian Entrenchment: Opening up or Digging in? African Affairs, 118, 238-258. 
https://doi.org/10.1093/afraf/ady050

Proença, T., Proença, J. F., \& Teixeira, I. (2020, February). The Role of Error Management Culture and Leadership on Failures and Recovery in Services. In H. Nóvoa, M. Drăgoicea, \& N. Kühl (Eds.), Exploring Service Science. IESS 2020. Lecture Notes in Business Information Processing (Vol. 377, pp. 391-398). Cham: Springer. https://doi.org/10.1007/978-3-030-38724-2 28

Rigobon, R. (2019). Contagion, Spillover, and Interdependence. Economía, 19, 69-99. https://doi.org/10.1353/eco.2019.0002

Ruffa, C., Rietjens, S., \& Nygren, E. (2020). Resilience and Conflict Resolution: UN Peacekeeping in Mali. In E. Cusumano, \& S. Hofmaier (Eds.), Projecting Resilience across the Mediterranean (pp. 189-203). Cham: Palgrave Macmillan. https://doi.org/10.1007/978-3-030-23641-0 10

Saldaña, J. (2021). The Coding Manual for Qualitative Researchers. Thousand Oaks, CA: SAGE Publications Limited.

Scott, N., \& Laws, E. (2006). Tourism Crises and Disasters: Enhancing Understanding of System Effects. Journal of Travel \& Tourism Marketing, 19, 149-158. https://doi.org/10.1300/J073v19n02 12

Shevchenko, V. V. (2019). The Reform of the Higher Education of Ukraine in the Conditions of the Military-Political Crisis. International Journal of Educational Development, 65, 237-253. https://doi.org/10.1016/j.ijedudev.2018.08.009

Shrestha, A. D., Andersen, J. G., Neupane, D., Ghimire, S., Campbell, C., \& Kallestrup, P. (2020). Protocol for Systematic Literature Review on Implementation of Cervical Cancer Screening and Associated Factors in Nepal from 2000 to 2018. Journal of Global Health Reports, 4, e2020023. https://doi.org/10.29392/001c.12505

Shrivastava, P. (1994). The Evolution of Research on Technological Crises in the US. Journal of Contingencies and Crisis Management, 2, 10-20. https://doi.org/10.1111/j.1468-5973.1994.tb00022.x

Silva, D. A. S. (2020). Physical Inactivity as a Risk Factor to Mortality by Ischemic Heart Disease during the Economic and Political Crisis in Brazil. PeerJ, 8, e10192.

https://doi.org/10.7717/peerj.10192

Silva, M., Resurrección, D. M., Antunes, A., Frasquilho, D., \& Cardoso, G. (2020). Impact of Economic Crises on Mental Health Care: A Systematic Review. Epidemiology and Psychiatric Sciences, 29, e7. https://doi.org/10.1017/S2045796018000641

Sousa, L. R. M. D., Segall-Corrêa, A. M., Ville, A. S., \& Melgar-Quiñonez, H. (2019). Food Security Status in Times of Financial and Political Crisis in Brazil. Cadernos de Saude Publica, 35, e00084118. https://doi.org/10.1590/0102-311x00084118

Souto, B. F. F. (2009). Crisis and Corporate Social Responsibility: Threat or Opportunity? International Journal of Economic Sciences and Applied Research, 2, 36-50.

Stegenga, K., Liu, Q., \& Haase, J. (2020). Resilience in Pediatric Oncology. In P. Hinds, \& L. Linder (Eds.), Pediatric Oncology Nursing (pp. 63-77). Cham: Springer. https://doi.org/10.1007/978-3-030-25804-7 4

Straub, A. M., Gray, B. J., Ritchie, L. A., \& Gill, D. A. (2020). Cultivating Disaster Resilience in Rural Oklahoma: Community Disenfranchisement and Relational Aspects of Social Capital. Journal of Rural Studies, 73, 105-113.

https://doi.org/10.1016/j.jrurstud.2019.12.010

Susser, D., Roessler, B., \& Nissenbaum, H. (2019). Technology, Autonomy, and Manipulation. Internet Policy Review, 8. https://doi.org/10.14763/2019.2.1410

Tew, R. (n.d.). The Struggle You're in Today Is Developing the Strength You Need Tomor- 
row. https://www.pinterest.com/pin/270497521357411095/

Tippens, J. A. (2020). Urban Congolese Refugees' Social Capital and Community Resilience during a Period of Political Violence in Kenya: A Qualitative Study. Journal of Immigrant \& Refugee Studies, 18, 42-59. https://doi.org/10.1080/15562948.2019.1569744

Tocci, G., Presta, V. \& Volpe, M. (2020). Hypertensive Crisis Management in the Emergency Room: Time to Change? Journal of Hypertension, 38, 33-34. https://doi.org/10.1097/HJH.0000000000002235

UKEssays (November 2018). Types of Crisis with Special Reference Management Essay. https://www.ukessays.com/essays/management/types-of-crisis-with-special-referencemanagement-essay.php?vref $=1$

Uwanno, B. (2009). Economic Crisis and Political Crisis in Thailand: Past and Present. NYU Law Review, 4, 141-200.

Varol, O. O. (2012). The democratic coup d'état. Harvard International Law Journal, 53, 291.

Weisæth, L., Knudsen Jr., Ø., \& Tønnessen, A. (2002). Technological Disasters, Crisis Management and Leadership Stress. Journal of Hazardous Materials, 93, 33-45. https://doi.org/10.1016/S0304-3894(02)00036-5

Wenzelburger, G., \& Wolf, F. (2015). Policy Theories in the Crisis? ICPP.

Wicks, D. (2017). The Coding Manual for Qualitative Researchers. Qualitative Research in Organizations and Management: An International Journal, 12, 169-170. https://doi.org/10.1108/QROM-08-2016-1408

Will Coronavirus Shift Global Investment from China to India? 13 February 2020. https://www.indiatoday.in/business/story/will-coronovirus-shift-global-investment-fro m-china-to-india-1646024-2020-02-13

Yelkikalan, N., \& Köse, C. (2012). The Effects of the Financial Crisis on Corporate Social Responsibility. International Journal of Business and Social Science, 3, 292-300.

Yin, R. K. (2014). Case Study Research: Design and Methods (Applied Social Research Methods). Thousand Oaks, CA: Sage Publications.

Zappettini, F., \& Krzyżanowski, M. (2019). The Critical Juncture of Brexit in Media \& Political Discourses: From National-Populist Imaginary to Cross-National Social and Political Crisis. Critical Discourse Studies, 16, 381-388. https://doi.org/10.1080/17405904.2019.1592767

Zhang, Y., Suhaimi, N., Azghandi, R., Joseph, M. A., Kim, M., Griffin, J., \& Parker, A. G. (2020, April). Understanding the Use of Crisis Informatics Technology among Older Adults. In Proceedings of the 2020 CHI Conference on Human Factors in Computing Systems (pp. 1-13). New York: Association for Computing Machinery.

Zubair, S., Kabir, R., \& Huang, X. (2020). Does the Financial Crisis Change the Effect of Financing on Investment? Evidence from Private SMEs. Journal of Business Research, 110, 456-463.

\section{Abbreviation}

(AIT): Artificial Intelligent Technology 